\title{
COMPARATIVE STUDY FOR USING LIME AND CEMENT KILN DUST FOR MUNICIPAL SLUDGE TREATMENT.
}

\author{
Hazem I. Saleh ${ }^{1}$, Magdy A. Zahran ${ }^{2}$ \\ Amal A. Nasser ${ }^{2}$, Eman M. Elsehaity ${ }^{4}$ \\ 1. Civil Engineering Department, Faculty of Engineering, Menoufia University, Egypt (32511) \\ hazemsaleh1@hotmail.com \\ 2. Chemistry Department, Faculty of Science, Menoufia University, Egypt (32511) \\ magdyzahran@gmail.com \\ 3. Civil Engineering Department, Faculty of Engineering, Menoufia University, Egypt (32511) \\ Dr.AmalNasser@gmail.com Tel.0020100 0077477 (Corresponding Author) \\ 4. Civil Engineering Department, Faculty of Engineering, Menoufia University, Egypt (32511) \\ emanessehaity@gmail.com
}

\begin{abstract}
:
Municipal Sludge Treatment is a first priority issue in high populated countries like Egypt. Building materials properties were employed in treating sewage sludge. Adding water to cement and lime creates alkaline media, which raises $\mathrm{pH}$ of sludge for certain period of time. High $\mathrm{pH}$ ensures getting rid of pathogens in the treated sludge. Unlike industrial wastes, Cement Kiln Dust is similar to Cement composition with less specification. An investigation of several alkaline building materials was conducted to compare the influence of mixing them with sewage sludge. Using by-product Cement Kiln Dust proved to be effective and was lime competitive. Fresh collected Cement Kiln Dust has a larger potential in raising pH than that of stored one. Cement Kiln Dust as well as lime achieved Class B specifications. Using Cement Kiln Dust proved to be effective and cheap treatment of Municipal Sludge.

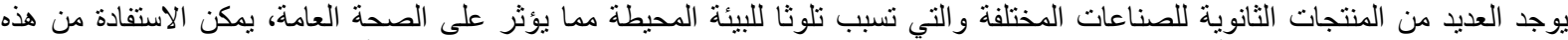

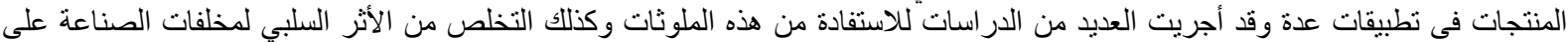

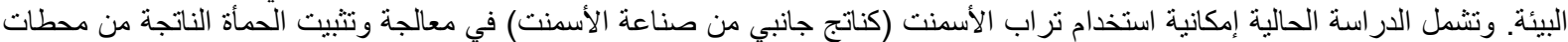

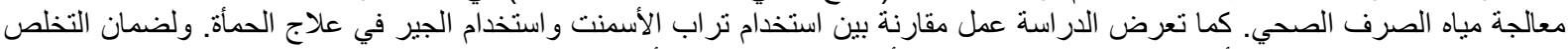

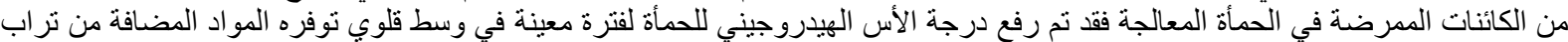

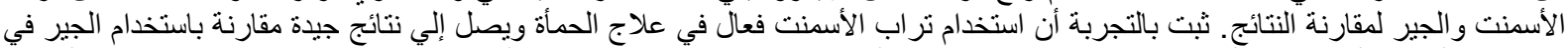

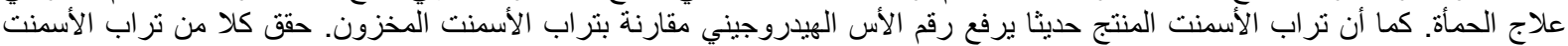

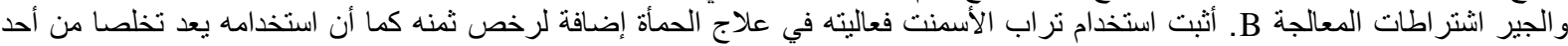

Keywords: Cement Kiln Dust; Lime, Municipal Sludge; Wastewater Treatment; Sludge Pathogens; Sludge Parasites.

\section{Introduction:}

Sewage Sludge is any "solid, semisolid, or liquid residue generated during the treatment of domestic sewage in treatment works composed of constituents collected or produced at different stages of the wastewater treatment process[1-4]. There are different types of sludge such as Primary, Biological, Mixed, Digested, Physico-chemical and Mineral sludge [5]. The main purpose for sludge treatment is to decrease the moisture content and to lower the volume for easiness of follow-up process, utilization and transportation. Hygienization and stabilization is essential in sludge treatment [4]. Although there has been some debate over the exact definition of stabilization, it generally includes three main parts, which are pathogen reduction or disinfection, elimination of offensive odors and a general improvement of aesthetics, minimization in the potential for putrification [6].

Sludge is generally conditioned before thickening and dewatering. Two types of conditioning chemicals are used to enhance the treatability of the sludge. First, Mineral chemicals such as iron salts and lime are used. These chemicals are frequently found in filter press applications. Second, organic chemicals such as coagulants and flocculants are used. The most common type of flocculants encountered are cationic in nature [5, 7]. Lime is used after dewatering to stabilize the sludge [5]. The chemical fixation process involves combining treated sludge with stabilizing agents, such as cement, sodium silicate, pozzolan, or lime, to chemically react with or encapsulate sludge particles [2]. 
CKD is a fine grained alkaline material which is a by-product of cement clinker production. In Egypt, approximately one million tons of cement dust are discarded annually from cement manufacturing [8,9]. The emissions have a negative impact on the environment and causes serious problems on the national level. Lime and $\mathrm{CKD}$ have the same effective material which is $\mathrm{CaO}[10]$.

\section{The Research Objective:}

The current study concerns the use of cement kiln dust (a by-product from cement industry) in treatment / stabilization of municipal sludge resulting from wastewater treatment plants comparatively with lime usage. The above may present an added value to the currently problematic waste that requires financial and logistics measure for its safe disposal; this shall also increase the potential of reuse of such byproducts and waste in agricultural fertilizes.

\section{Materials and Methods \\ 3.1 Materials \\ 3.1.1 Sewage Sludge}

Sewage sludge samples were collected from the waste water treatment plant (WWTP) of El koum El Akhdar, affiliated village of Shebien el koum, Menofya governorate, Egypt. This WWTP serves around 10000 inhabitants with an influent flow rate of about $3000 \mathrm{~m}^{3} /$ day. The treatment plant consists of an extended aeration activated sludge process. Treated effluent is disinfected by chlorination and is discharged to a drain. Excess sludge from the secondary clarifier is thickened and digested then dewatered in sludge drying beds and finally disposed in a landfill site or sold to a local contractor. The sludge samples were taken from the sludge effluent sent to drying beds after the aerobic digester and from drying beds after partially dried. Raw sludge average $\mathrm{pH}$ was 6.65 . This average was calculated for fresh liquid, 3days, one week, 3 weeks sewage sludge.

\subsubsection{Additives}

\subsubsection{CKD-1}

A by-pass kiln dust sample collected from BanySouief Portland Cement Company, which analyzed by x-ray diffract meter and DTA analysis as shown in Table (1).

Table (1) XRD \& DTA analysis of CKD-1(BanySowief Portland Cement Company).

\begin{tabular}{|c|c|c|c|c|c|c|c|c|}
\hline \multicolumn{10}{|c|}{ Oxide Content \% } \\
\hline $\mathrm{SiO2}$ & $\mathrm{Al2O3}$ & $\mathrm{Fe} 2 \mathrm{O3}$ & $\mathrm{CaO}$ & $\mathrm{MgO}$ & $\mathrm{SO3}$ & $\mathrm{K} 2 \mathrm{O}$ & $\mathrm{Na2O}$ & $\mathrm{Cl}$ \\
\hline 9.1 & 3.14 & 2.44 & 46.1 & 0.64 & 2.35 & 9.083 & 2.288 & 11.608 \\
\hline
\end{tabular}

\subsubsection{CKD-2}

A by-pass kiln dust sample collected from Torah Portland Cement Company, which analyzed by x-ray diffract meter and DTA analysis as shown in Table (2).

Table (2) XRD and DTA analysis of CKD-2 (Torah Portland Cement Company)

\begin{tabular}{|c|c|c|c|c|c|c|c|}
\hline \multicolumn{7}{|c|}{ Oxide Content \% } \\
\hline $\mathrm{SO}_{3}$ & $\mathrm{~K}_{2} \mathrm{O}$ & $\mathrm{Na}_{2} \mathrm{O}$ & $\mathrm{MgO}$ & $\mathrm{CaO}$ & $\mathrm{Fe}_{2} \mathrm{O}_{3}$ & $\mathrm{Al}_{2} \mathrm{O}_{3}$ & $\mathrm{SiO}_{2}$ \\
\hline 5.28 & 4.18 & 2.84 & 7.76 & 13.8 & 1.47 & 1.62 & 17.15 \\
\hline
\end{tabular}

\subsubsection{Lime-1}

A lime sample from a local distributer who provides other building materials the lime producer and specifications were unknown.

\subsubsection{Lime-2}

A lime sample from Torah Portland Cement Company was used.

\subsubsection{Calcium Hydroxide $\mathrm{Ca}(\mathrm{OH}) 2$}

Used material is Extra pure calcuim hydroxide of 95\% purity manifactured by Alpha Chemika (made in India) an ISO 9001:2000 certified company.

Table (3):Composition of $\mathrm{Ca}(\mathrm{OH})_{2}$

\begin{tabular}{|l|l|l|}
\hline \multicolumn{2}{|l|}{ Purity } & $95 \%$ \\
\hline \multicolumn{2}{|l|}{ Maximum limits of impurities : } \\
\hline Chloride(Cl) & $0.04 \%$ & \\
\hline Sulphate(SO4) & $0.4 \%$ & \\
\hline Iron (Fe) & $0.1 \%$ & \\
\hline Heavy metals & $\begin{array}{l}\text { (as Pb)0.005\% (as } \\
\text { sulphate) 2.5\% }\end{array}$ \\
\hline
\end{tabular}

\subsection{Methods}

\subsubsection{Using Fresh Sludge :}

In this process, lime, calcuim hydroxid and CKD is added to untreated biosolids to raise the $\mathrm{pH}$.

Lime dose was determined using emprical equation: Lime dose $=4.2+1.6$ (T.S.) $\quad$ equation (1)

Lime dose is expressed in gram of $\mathrm{Ca}(\mathrm{OH})_{2} /$ liter of sludge.

T.S.: total solids fraction in the sludge.

This dose was calculated to predict where to start for each lime and CKD in order to determine the optimum dose as well as trial and error method. Total solids of $100 \mathrm{ml}$ sample were calculated according to [11].

Table (4) Calculation of W2 of the samples used to calculate total solids.

\begin{tabular}{|c|c|c|}
\hline $\begin{array}{c}\text { Sample } \\
\text { no. }\end{array}$ & $\begin{array}{c}\text { Weight of sample after } \\
\text { drying }(\mathrm{g})\end{array}$ & $\begin{array}{c}\text { W2 (weight of dried } \\
\text { sample) }(\mathrm{g})\end{array}$ \\
\hline 1 & $\begin{array}{c}\text { W2a }=4.7 \\
\text { W2b }=4.29\end{array}$ & 9.2 \\
\hline 2 & $\begin{array}{c}\text { W2a }=4.4 \\
\text { W2 } \mathrm{b}=3.2 \\
\text { W2 }=1.49\end{array}$ & 9.2 \\
\hline
\end{tabular}


T.S. for sludge sample:

$\mathrm{T} . \mathrm{S}=\left[(9.2-1.7) * 10^{\wedge} 6\right] / 100=74700 \mathrm{mg} / \mathrm{l}=74.7 \quad \mathrm{~g} / \mathrm{l}$

Calculating lime dose for the sample: According to the empirical equation used in ref.[12] a guide dose of lime was calculated as below:

Lime dose $=4.2+1.6($ T.S. $)=4.2+1.6 * 74.7$

$=123.72 \mathrm{gm} / \mathrm{lit}$. $=12.4 \mathrm{gm} / 100$ milli lit.

\subsubsection{Using Dried Sludge}

Dried sludge was used to calculate lime dose. Sludge sample was one week old. To minimize errors the dried weight and water content used to determine total solids of the sample was calculated three times. Referring to calculations in section (3.2.1), a sample of $9 \mathrm{gm}$ was investigated to relate the lime dosage required with the solids concentration.

Three plates were used to oven dry the sample at 105 $\mathrm{C}$ for 24 hours and the results were recorded.

An average of water content of the three samples was calculated and used to calculate total solids.

Table (5): Water Content of Sludge Samples.

\begin{tabular}{|c|c|c|c|c|c|}
\hline & $\begin{array}{c}\text { plate } \\
\text { weight }\end{array}$ & $\begin{array}{c}\text { wet } \\
\text { sample } \\
\text { weight }\end{array}$ & W1 & W2 & Wc $\%$ \\
\hline I & 39.9873 & 10.0921 & 50.0794 & 43.4442 & 13.24936 \\
\hline II & 40.8405 & 10.0634 & 50.9039 & 44.8852 & 11.823652 \\
\hline III & 42.5381 & 10.0563 & 52.5944 & 45.8102 & 12.899092 \\
\hline \multicolumn{4}{|c|}{ Average Wc\% } & 12.657368 & $\approx 12.7$ \\
\hline
\end{tabular}

T.S. $\%=100-\mathrm{Wc} \%=100-12.7=87.3 \%$

Total solids in 9 grams of sludge $=0.873 * 9$ $=7.8608369 \approx 7.86 \mathrm{~g}$

Lime Dose $=4.2+1.6 * 7.86=16.777339 \mathrm{gm}$ of $\mathrm{Ca}(\mathrm{OH})_{2} /$ litre of sludge

Dose $/ 100 \mathrm{ml}$ of sludge $=$ Lime dose $/ 10=16.777339 / 10=1.6 \mathrm{gm} \mathrm{Ca}(\mathrm{OH}) 2 / 100 \mathrm{ml}$ of sludge.

Using calculated dose of lime and CKD from section (3.2.1) and mixing it with a $100 \mathrm{ml}$ of sludge the $\mathrm{pH}$ results showed that the dose was too high for CKD so it was decreased till it gave $\mathrm{pH}$ readings $<12$ and then was raised gradually till it achieved $\mathrm{pH}$ condition according to EPA requirements. Using calculated dose from section (3.2.2) gave high $\mathrm{pH}$ values for $\mathrm{Ca}(\mathrm{OH})_{2}$ so it was decreased to $0.5 \mathrm{~g} / 100 \mathrm{ml}$ but for lime and CKD the dose was $1 \mathrm{~g} / 100 \mathrm{ml}$ and to ensure not over dosing smaller doses were used and $\mathrm{pH}$ results were checked.

There were five mixes of sludge treated with two samples of CKD, two samples of lime and a pure $\mathrm{Ca}(\mathrm{OH})_{2}$. Experiments were carried-out to compare $\mathrm{pH}$ readings to optimize the treating dose. According to the calculations of T.S. and lime dose, range of doses was experimented to optimize each additive dose. Doses which kept $\mathrm{pH}>12$ after 2 hours and held $\mathrm{pH}>11.5$ after 24 hours were chosen to test its pathogenic content in El Borg Lab.

To meet Class B requirements using lime stabilization, the $\mathrm{pH}$ of the biosolids must be elevated to more than 12 for 2 hours and subsequently maintained at more than 11.5 for more 22 hours according to (EPA, 40 CFR Part 503 ,2003). Using obtained results curves were drawn for each sample using CKD and lime and calcium hydroxide optimum dose was determined.

\section{Test Results:}

Figures from (1 to 5) illustrate relationship between $\mathrm{pH}$ and time for different doses. $\mathrm{pH}$ was measured for each dose as drawn in Figure (1).

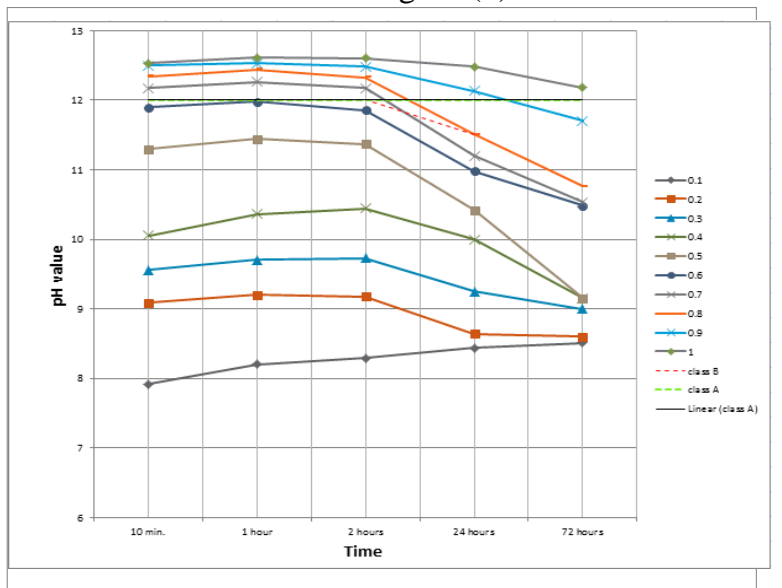

Figure (1) Effect of Increasing CKD-1 Dose on Sludge Sample $\mathrm{pH}$.

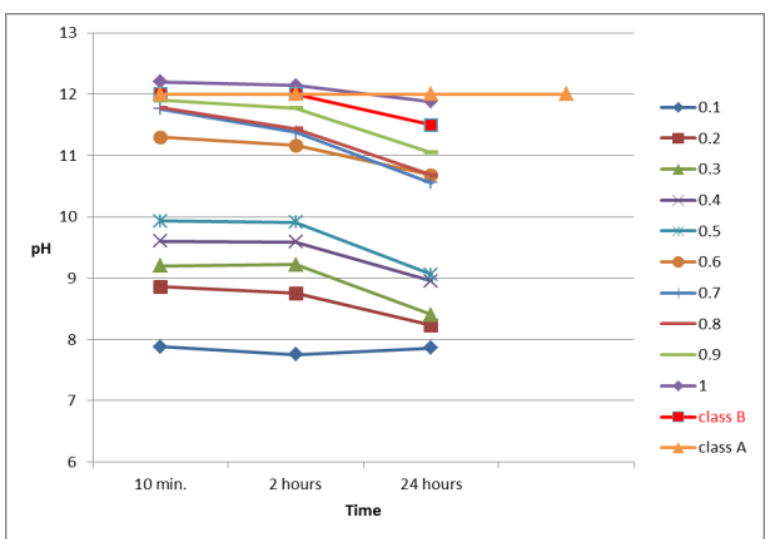

Figure (2) Effect of Increasing CKD-2 Dose on Sludge Sample $\mathrm{pH}$.

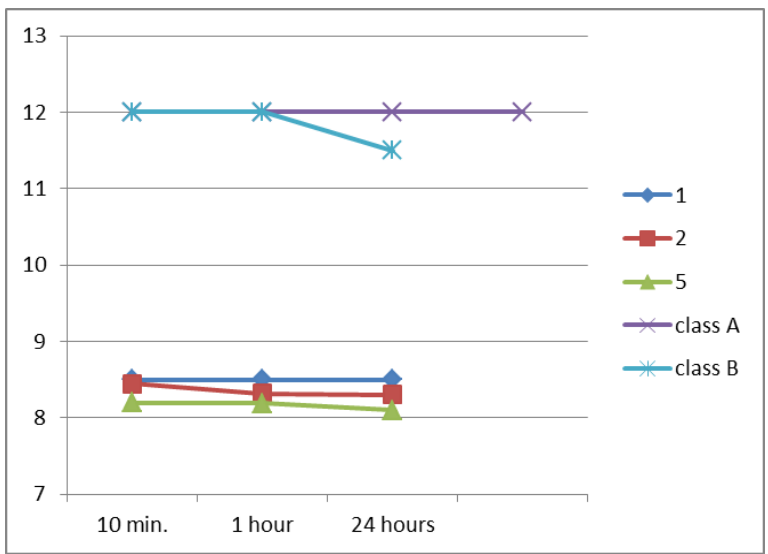

Figure (3) Effect of Increasing Lime-1 Dose on Sludge Sample $\mathrm{pH}$. 


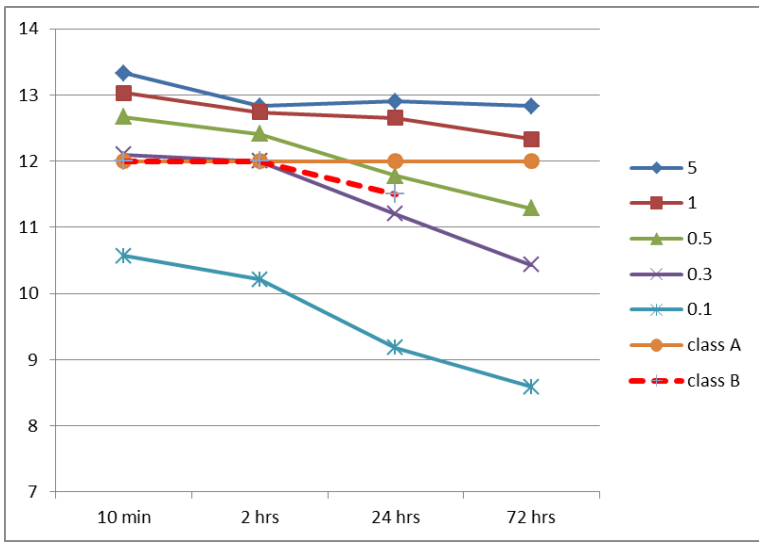

Figure (4) Effect of Increasing Lime-2 Dose on Sludge Sample $\mathrm{pH}$.

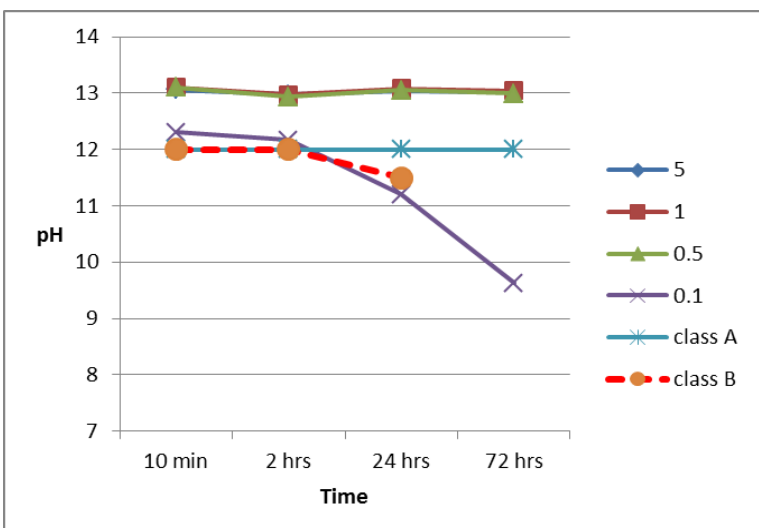

Figure (5) Effect of Increasing $\mathrm{Ca}(\mathrm{OH})_{2}$ Dose on Sludge Sample $\mathrm{pH}$.

Relation between additive dose and $\mathrm{pH}$ of sludge sample after 72hours is shown in figure (6) for all additives. Figure (7) illustrates the relation between $\mathrm{pH}$ and time for 72 hours. The optimum dose was chosen for each sludge treatment. CKD-1,CKD-2 and L-2 dose was $1 \mathrm{~g} / 100 \mathrm{ml}$ and for $\mathrm{Ca}(\mathrm{OH})_{2}$ was 0.5 $\mathrm{g} / 100 \mathrm{ml}$ of sludge. A comparison between $\mathrm{pH}$ results of CKD-1 and L-2 is shown in figure (8). Figure (9) compares $\mathrm{pH}$ readings for different additives on different periods.

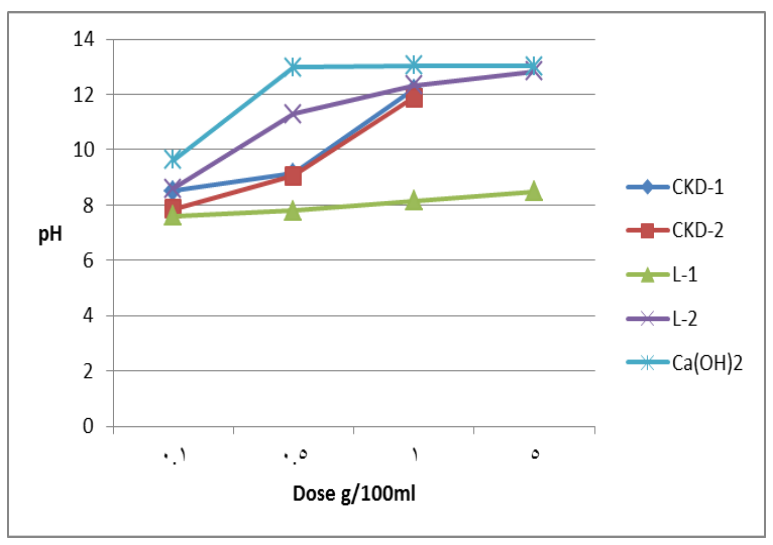

Figure (6) Relation between Additive Dose and Sludge Sample pH after 72hours.

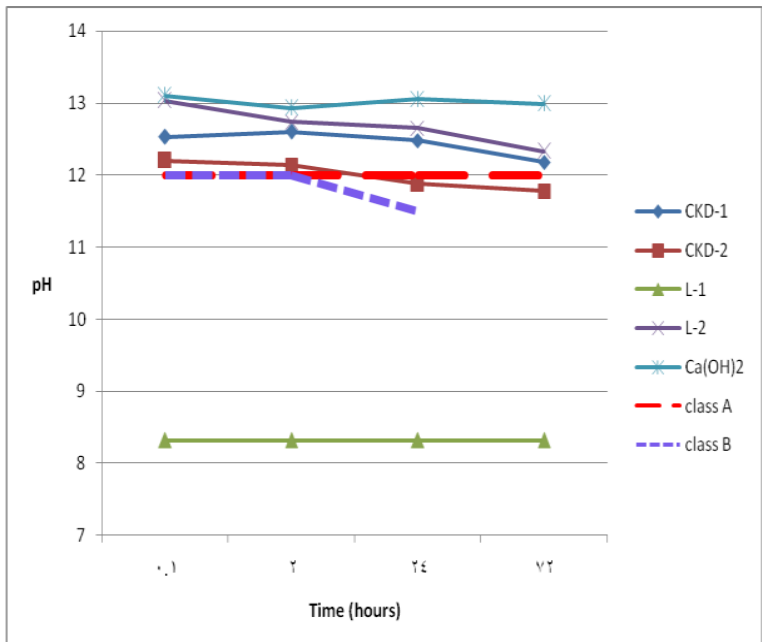

Figure (7) Relation between Sludge Sample pH and Time for optimum dose.

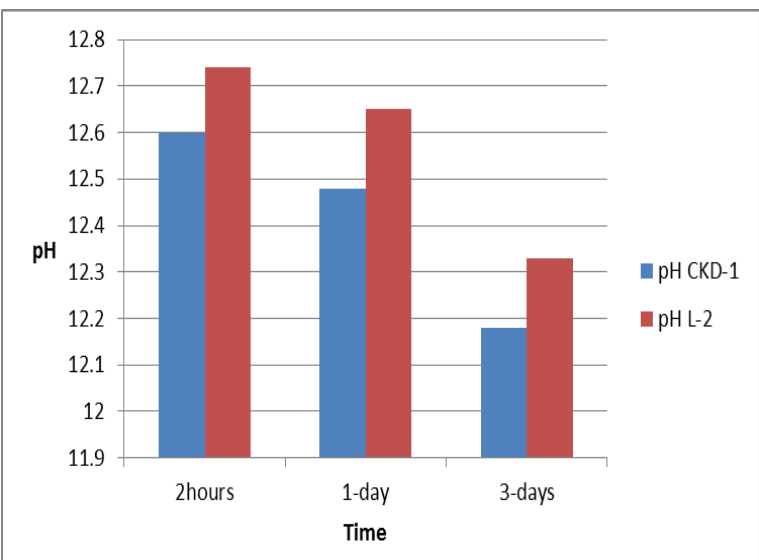

Figure (8): Comparison between pH Results and Time Using Optimum Dose for CKD1 and Lime.

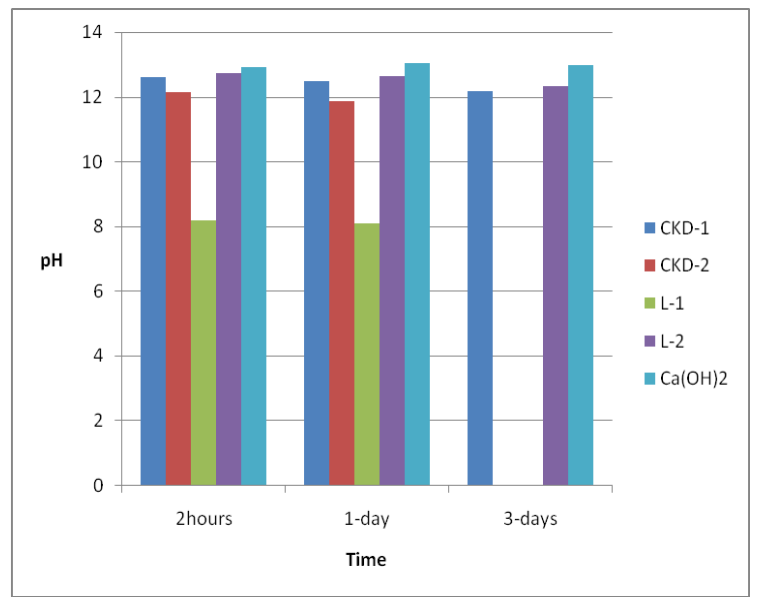

Figure (9) pH Readings for Different Additives on Different Periods. 
Pathogens were tested for chosen samples in El Borg Lab. The following results were recorded.

Table (6) Parasite Analysis Results for treated sludge

\begin{tabular}{|c|c|c|c|c|c|}
\hline \multicolumn{6}{|c|}{ Parasite Analysis Results } \\
\hline \multirow{3}{*}{$\begin{array}{c}\text { Untreat } \\
\text { ed } \\
\text { sludge } \\
\text { parasite } \\
\text { analysi } \\
\mathrm{s} \\
\text { results }\end{array}$} & \multicolumn{2}{|c|}{ Helminthes } & \multicolumn{3}{|c|}{ Protozoa } \\
\hline & $\begin{array}{c}\text { Ov } \\
\text { a }\end{array}$ & Larva & $\begin{array}{l}\text { Trophozo } \\
\text { ites }\end{array}$ & Cysts & $\begin{array}{c}\text { Oocyst } \\
\text { s } \\
(\mathrm{MZN})\end{array}$ \\
\hline & -ve & Nematodea & Amoebae & Amoebae & -ve \\
\hline $\begin{array}{l}\text { Treated } \\
\text { sludge } \\
\text { with } \\
\text { lime } \\
\end{array}$ & -ve & Nematodea & $\begin{array}{l}\text { Amoebae } \\
\text {, } \\
\text { flagylate } \\
\& \text { ciliate }\end{array}$ & Amoebae & -ve \\
\hline $\begin{array}{c}\text { Treated } \\
\text { sludge } \\
\text { with } \\
\text { CKD }\end{array}$ & -ve & Nematodea & Amoebae & Amoebae & -ve \\
\hline
\end{tabular}

Table (7) Bacterial Analysis Results for untreated and treated sludge.

\begin{tabular}{|c|c|c|c|}
\hline \multicolumn{4}{|c|}{ Bacterial Analysis Results } \\
\hline & $\begin{array}{l}\text { Untreated } \\
\text { Sludge }\end{array}$ & $\begin{array}{c}\text { Treated } \\
\text { with Lime }\end{array}$ & $\begin{array}{c}\text { Treated } \\
\text { with CKD }\end{array}$ \\
\hline Odor & Odorless & Odorless & Odorless \\
\hline Color & Colorless & Colorless & Colorless \\
\hline Aspect & Clear & Clear & Clear \\
\hline Plate count & $\begin{array}{c}>100 \\
\mathrm{CFU} / \mathrm{ml}\end{array}$ & $\begin{array}{c}>100 \\
\mathrm{CFU} / \mathrm{ml}\end{array}$ & $\begin{array}{c}\text { No } \\
\text { growth/ml }\end{array}$ \\
\hline $\begin{array}{c}\text { Most } \\
\text { probable } \\
\text { number(Colli } \\
\text { form Bacilli) }\end{array}$ & $\begin{array}{c}+180 \\
\text { Colliform } \\
\text { bacilli/10 } \\
0 \mathrm{ml}\end{array}$ & $\begin{array}{c}\text { No } \\
\text { Colliform } \\
\text { bacilli/10 } \\
0 \mathrm{ml}\end{array}$ & $\begin{array}{c}\text { No } \\
\text { Colliform } \\
\text { bacilli/10 } \\
0 \mathrm{ml}\end{array}$ \\
\hline $\begin{array}{c}\text { Most } \\
\text { probable } \\
\text { Number(E.Co } \\
\text { li) }\end{array}$ & $\begin{array}{l}+\mathrm{ve} \text { for } \\
\text { E.Coli }\end{array}$ & $\begin{array}{c}\text { No } \\
\text { E.Coli/10 } \\
\text { Oml }\end{array}$ & $\begin{array}{c}\text { No } \\
\text { E.Coli/10 } \\
\text { Oml }\end{array}$ \\
\hline $\begin{array}{c}\text { Pseudomonas } \\
\text { aeruginosa }\end{array}$ & $\begin{array}{l}\text { No } \\
\text { growth }\end{array}$ & $\begin{array}{c}\text { No } \\
\text { growth }\end{array}$ & $\begin{array}{l}\text { No } \\
\text { growth }\end{array}$ \\
\hline $\begin{array}{c}\text { Staphylococc } \\
\text { us aureus }\end{array}$ & $\begin{array}{l}\text { No } \\
\text { growth }\end{array}$ & $\begin{array}{l}\text { No } \\
\text { growth }\end{array}$ & $\begin{array}{l}\text { No } \\
\text { growth }\end{array}$ \\
\hline $\begin{array}{c}\text { Enterococcus } \\
\text { Spp. }\end{array}$ & $\begin{array}{l}\text { No } \\
\text { growth }\end{array}$ & $\begin{array}{l}\text { No } \\
\text { growth }\end{array}$ & $\begin{array}{l}\text { No } \\
\text { growth }\end{array}$ \\
\hline
\end{tabular}

\section{Discussions}

Additive dose is related to total solids of the sludge sample because the experiment was done on different sludge samples taken in different days. Figure (1) showed an increase in $\mathrm{pH}$ with time at first 2 hours then decreased gradually in the following 22 hours and after 72 hours only samples with $\mathrm{pH}>12$ was chosen. The high $\mathrm{pH}$ creates an environment that halts or substantially retards the microbial reactions that can otherwise lead to odor production and vector attraction. The biosolids will not putrefy, create odors, or pose a health hazard so long as the $\mathrm{pH}$ is maintained at this level.
For lime and CKD two samples of the material were used in treating sewage sludge and gave different results. The dose of Lime (L-1) was calculated from the equation to be $12.4 \mathrm{~g} / 100 \mathrm{ml}$. It was increased to be $20 \mathrm{~g} / 100 \mathrm{ml}$ in a trial to raise $\mathrm{pH}$ above 12 , but in vain $\mathrm{pH}$ still under 12 although the sample was stirred for half an hour with magnetic stirrer. The calculated dose of Lime (L-2) was $1.6 \mathrm{~g} / 100 \mathrm{ml}$ a dose of $1 \mathrm{~g} / 100 \mathrm{ml}$ raised the $\mathrm{pH}$ above 12 and kept it above 12 for 72 hours. The dose of Cement Dust (CKD-1) was gradually elevated from $0.1 \mathrm{~g} / 100 \mathrm{ml}$ to $1 \mathrm{~g} / 100 \mathrm{ml}$. The dose which kept $\mathrm{pH}$ above 12 for 72 hours was $1 \mathrm{~g} / 100 \mathrm{ml}$. The dose CKD-2 of $1 \mathrm{~g} / 100 \mathrm{ml}$ was not enough to elevate the $\mathrm{pH}$ above 12 and keep it like that of 72 hours. It can be noticed that CKD-1 has higher $\mathrm{CaO}$ percentage than $\mathrm{CKD}-2$ which directly affected the ability of CKD in raising the $\mathrm{pH}$ of the sample.

The difference in results between CKD-1 and CKD-2 is due to the age of CKD sample which in case of CKD-1 was a fresh sample from the factory and was used at 9 days old. In case of CKD-2 the sample was 2 months old and was left in open air before using. The calcium oxide content was higher for CKD-1 than that of CKD-2, so CKD-1 gave better results. The difference in results between L-1 and L-2 is due to the quality of lime used in case of L-2. A known brand right packed and stored was used unlike L-1. Also calcium hydroxide was used and was very effective as a dose of $0.5 \mathrm{~g} / 100 \mathrm{ml}$ achieved the $\mathrm{pH}$ condition but also very expensive when compared with lime and CKD so it was not economically effective.

Using lime dose of $1 \mathrm{~g} / 100 \mathrm{ml}$ of sludge was effective. This may be due to percentage of $\mathrm{CaO}$ in CKD-1 was $46.1 \%$. This is close to the amount of $\mathrm{CaO}$ in lime used by EPA study which determined lime dose equation.

The comparison between L-1, L-2, CKD-1, CKD-2, $\mathrm{Ca}(\mathrm{OH})_{2}$ indicates that $\mathrm{Ca}(\mathrm{OH})_{2}$ gives best $\mathrm{pH}$ results but it is not economically effective as it is very expensive compared to other used materials. L-2 gave better $\mathrm{pH}$ results than that of CKD-1 with slight different after 2, 24, 72 hours but both L-2 and CKD1 fulfill $\mathrm{pH}$ constraints according to Class A and B as listed in EPA regulations.

This study showed that liming improved the microbiological quality of sludge. The efficiency of sludge liming in terms of the elimination of pathogenic microorganisms depends on the $\mathrm{pH}$ achieved in the sludge and duration of liming activity. Salmonella elimination requires keeping $\mathrm{pH}$ of sludge at $\mathrm{pH} 11$ and 12 in the first two hours. Raising the $\mathrm{pH}$ of the sample retards pathogens and this happens because the internal $\mathrm{pH}$ of most living cells is close to 7 . When there is even a slight change in the $\mathrm{pH}$, this can be extremely harmful for pathogens and parasites. 
It is harmful because the chemical processes of the cell are sensitive to the concentration of hydrogen and hydroxide ions. The results demonstrated the very strong inactivation of salmonella during liming. Liming improved the microbiological quality of sludge provided that the $\mathrm{pH}$ was maintained at higher than 11 for two hours (met Class B) or for 24 hours (met Class A). Inactivation of helmet eggs required increase the $\mathrm{pH}$ to higher than 12 for more than 24 hours.

\section{Conclusion}

Using Lime or Cement Kiln Dust will give almost equal results in treating sewage sludge effectively. This is constrained by using high quality manufactured lime packed and stored correctly. On the other hand, using CKD -by-product of cement manufacture- which causes environmental problems is also very effective in stabilizing sewage sludge. So, it is recommended to use CKD instead of lime for this purpose to produce treated sewage sludge that can be used in controlled agriculture according to environmental laws.

The use of sewage sludge in agriculture in Egypt may offer the most sustainable and beneficial use of sewage sludge under Egyptian conditions. It may offer the most economical route of sludge disposal because the Egyptian farmers are prepared to pay for any source of organic manure. About 0.66 million tons of the dried sewage sludge have already been sold to farmers in 2007, which represent more than $85 \%$ of the total produced sewage sludge from all WWTPs in Egypt according to HCWW data.

\section{References}

[1] Environmental Regulations and Technology (EPA), Control of Pathogens and Vector Attraction in Sewage Sludge, (Including Domestic Septage) CFR Part 503, EPA/625/R-92/013 Revised July 2003.

[2] D.E. Meeroff and F. Bloetscher, Sludge Management, Processing, Treatment, and Disposal, Florida Water Resources Journal, Nov. (1999), pp 23-25.

[3] M. Ghazy, T. Dockhorn, and N. Dichtl, Sewage Sludge Management in Egypt: Current Status and Perspectives towards a Sustainable Agricultural Use, World Academy of Science, Engineering and Technology, Vol. 57, (2009), pp 299-307.

[4] P. Lei, Sludge Treatment and Disposal, MSc. Thesis, Central Ostrobothnia University Of Applied Sciences, 2010, 152 pages.

[5] SNF Floerger handbook, Sludge Dewatering (2003), http://www.snf-group.com/category

[6] B. A. Acquisto, R.S. Reimers, J.E. Smith and S.D. Pillai, Factors Affecting Disinfection and Stabilization of Sewage Sludge, Proceedings of the Water Environment Federation, WEFTEC Session 61 (2006), pp 5345-5361.

[7] ISWA's Working Group on Sewage \& Waterworks Sludge, Sludge Treatment and Disposal: Management Approaches and Experiences, Environmental Issues Series, Vol. 7, (1997), pp 7-53.

[8] W.S. Adaska and D.H. Taubert, Beneficial Uses of Cement Kiln Dust, 50 ${ }^{\text {th }}$ Cement Industry Technical Conference, Miami, USA, 19-22 May (2008).

[9] T.A. Waly, A. M. Dakroury, G.O. El-Sayed and S.A. El-Salam, Assessment Removal of Heavy Metals Ions from Wastewater by Cement Kiln Dust, Journal of American Science, Vol.6, (2010), pp 1-12.

[10] W.M. Salem, W.F. Sayed, S.A. Halawa and R.B. Elamary, Physicochemical and Microbiological Characterization of Cement Kiln Dust For Potential Reuse in Wastewater Treatment, Ecotoxicology and Environmental Safety, Vol.119,(2015), pp 155-161.

[11] Standard Methods for the Examination of Water and Wastewater, American Public Health Association, American Water Works Association and Water Pollution Control Federation, 1999

[12] R.F. Noland, J.D. Edwards and M. Kipp, Full Scale Demonstration of Lime Stabilization, US Environmental Protection Agency EPA, (1987), 247 pages. 